\title{
Macroeconomic Link to Indian Capital Market: A Post-Liberalization Evidence
}

\author{
Hirak Ray, Joy Sarkar \\ Department of Commerce, University of North Bengal, Dt. Darjeeling, India \\ Email: hiraknbu@yahoo.com, jscnbu@gmail.com
}

Received 20 February 2014; revised 20 March 2014; accepted 27 March 2014

Copyright $@ 2014$ by authors and Scientific Research Publishing Inc.

This work is licensed under the Creative Commons Attribution International License (CC BY). http://creativecommons.org/licenses/by/4.0/

(c) (i) Open Access

\begin{abstract}
The present paper attempts to investigate the dynamic relation between the stock market and the select macroeconomic variables at log-levels, in India, for the period 1991:01 to 2008:04. Findings of the study show that the long-run stock market behavior is positively related to output and exchange rate, and negatively related to short- and long-term interests, money supply and inflation. The results of the causality and innovation analysis suggest that the stock market influences the economic activities, more specifically the industrial activities and the market is expected to be more sensitive to the shocks of itself over the projected period of the study.
\end{abstract}

\section{Keywords}

Stock Market, Macroeconomic Variables, Cointegration, Causality, Impulse Response Analysis, Forecast Error Variance Decomposition Analysis

\section{Introduction}

Stock market as an economic entity can survive if and only if movement in market remains closely intertwined with macro economy. The claim, in a sense, asserts that a well functioning market can only be treated as a boon to the society, in absence of which we have to search for alternative means of financing the real sector. This theme provoked many researchers to examine the case of market efficiency of both developed and developing economies. Findings of the studies vary but the importance of a competitive market in an economy is unquestionable [1]-[11]. The issue is much more important for the developing economies, thanks to the widespread belief that bank, not an ill-developed capital market, can usher economic prosperity. The current thesis aims to investigate the efficiency of Indian capital market to answer the queries-should we embrace or reject it.

There are few studies based on Indian experiences but all the exercises are subject to criticism on the count that either the studies have relied on orthodox methodology [12] or dealt with a short horizon [13]-[15], or ap- 
plied questionable methodology [14] [16] [17].

Again, some others have missed or ignored, at least partially, the most colorful and dynamic period of Indian economy in course of their study [18] [19]. Hence, we have little or no information about the macroeconomic link to Indian stock market, especially in the "free-economy" regime. Any objective answer about the form and direction of the link between stock market and fundamental macroeconomic factors is important in the sense that it may help to assess the level of efficiency of asset market, monitor and manage financial risk, price derivatives, find more exact solutions to problems of optimal portfolio selection [20] and develop a better understanding about the potential macroeconomic determinants of systematic financial risk [21].

Against this backdrop, the present paper aims to investigate the dynamic relationship and predictive causality between the select macroeconomic variables and the stock market in India. Precisely, objective of the current thesis is to suggest how the Indian stock market interacts, influences and is influenced by macro economy over a period that ranges from January, 1991 to April, 2008. The remainder of the study is structured as follows: Section 2 deals with the hypothesized relation between the stock market and select macroeconomic variables. Data and time period are provided in Section 3. Empirical methodology, findings and their interpretations are detailed in Section 4. Section 5 sums up the findings obtained from the study.

\section{Variables and Their Hypothesized Relationship}

Demirguc-Kunt and Levine [22] suggest that one of the differences between the developed and emerging economy is that, the former has a more matured and well-developed financial system which includes "advanced stock market" than the latter. Furthermore, economists often argue that the knowledge about the behaviour of market is essential as this sort of competitive market will assume an important role in the "changed regime" [23]-[25]. India, like the other emerging markets, is pursuing the "free-economy policy" from the early 1990's and during the last two decades there is a momentous change in each and every segments of her economy. Do these changes in macroeconomic variables and share price movements are inextricably intertwined? In our quest to investigate the relationship, especially in the "changed" regime, the macroeconomic variables are selected on the basis of the relevant literature in this field [7]-[9] [12] [15] [26]-[33] and by applying our own economic intuition [34]. Finally, Index of Industrial Production (IIP), Whole Sale Price Index (WPI), Money Supply (M3), Yield on 91-day Treasury Bills (YTB), Yield on Long-term (10-year) Government Bonds (YLGB) and an external competitiveness measure i.e., "the price of US dollar expressed in terms of domestic currency" $(\mathrm{EX})$ are chosen to estimate the relationship in aggregate with the stock prices in India.

In pursuing the objective of this study we hypothesized to estimate the model below:

$$
X_{t}=\left(\operatorname{Index}_{t}, Y T B_{t}, Y L G B_{t}, I I P_{t}, W P I_{t}, M 3_{t}, E x_{t}\right)
$$

The relationship between interest rate and stock price is at best fuzzy. Literature in this area is marked with contradictory evidences that, instead of solving, is sufficient to provoke further debate [34]-[36]. Following the theory of capital asset pricing model, some researchers argue that a rise in risk free rate will result in a decline in asset price and vice versa [4] [31] [37]. This view is, however, contested by many scholars [5] [35] [38], Furthermore, neo-classical and Keynsian view differs widely on the probable relationship between interest ratesavings-investment and asset price. While liberalists argue rise in interest rate at equilibrium level will attract more savings, thereby investment, economic growth and increase in asset prices. Alternatively, Keynsians propose fall in interest rate induces more consumption and the increased demand accelerate the growth of real sector that helps rise in asset prices. Virtually, it is a debate over: Is it supply or demand led growth strategy that can help in economic prosperity? Is there any positive role of interest in monitoring money supply, change in the level of economic activities and asset prices? Lessons of earlier studies of both finance and development economists suggest that interrelationship between interest, real sector and share prices is still unclear and researchers may find enough evidences in support of their position.

The relationship between stock return and real variables like output is well researched by the scholars. Fama [1] posits that the stock returns are positively related to output. Finance and economic literature widely supports that the allocative efficiency of stock market contributes in faster economic growth that adds to the vigor of asset market activities. Some scholars even argue that an efficient and well integrated capital market helps in global diversification of funds, greater options for risk reduction and encourage investment in "high-risk-high- 
return” projects [39]. The theory virtually endorses the policy of globalization that acclaims the strategy of diversification would help to maximize utilization of global resources and energies equity market around the world. But, an immaculate pricing mechanism of market can only help to keep its promise of increases in global productivity through wise allocation of resources. As the allocative efficiency of the market around the globe varies, we find divergent empirical evidences on stock return and output. Hsing [40], assuming stock prices affect output through wealth and investment, reports a short-term negative and long-term positive link between stock return and output in the context of emerging market like Brazil. The positive relationship between stock return and output is confirmed by several researchers through their empirical works based on a wide variety of economies and time-horizons [9] [12] [15]. But the direction of causation between stock market and economic growth measured in terms of industrial production is not clear. Hence, the issue deserves further attention and we hypothesize that industrial activity and stock market behavior is positively related to each other.

In his seminal work, Fama [1] suggests that there exists a negative relationship between stock (excess) returns and inflation because higher inflation rates induce higher nominal risk-free returns that results in a decrease in asset prices. DeFina [41] attributes the negative relationship due to nominal contracts that disallow the immediate adjustment of the firm's revenue and costs. Shen [42] argues that the portion of inflation rate unanticipated by the economic agents would surprise markets and cause dramatic movement of stock prices through changes in investor's expectation of compensation in the form of additional returns or yields. Chancharoenchai et al. [7] have also reviewed the complex relationship between inflation, volatility, risk premium and its impact on stock prices and confirmed the findings of earlier studies. However, Abdullahand Hayworth [37] observed that US stock returns are related positively to inflation. We hypothesize that both anticipated and unanticipated inflation inversely affect aggregate stock prices.

Neo-classical theorists suggest that in a credit constrained economy demand for money for investment would absorb all available funds of society leaving no scope for credit rationing. They argue that the demand deficiency does not matter; and the growth of developing economy is sub-optimal due to non-availability of investible resources. Thus, one can hypothesize, increase in money supply results in increase in investments causing higher economic growth which in turn contributes more activity in the stock market. However, the success of supply led growth strategy, among many other factors, largely depends on fiscal discipline in absence of which theorists believe that increase in money supply may cause higher inflation that may retard rather than encourage and promote economic growth and stock market activities [43] [44]. Abdullah and Hayworth [37], Mukherjee and Naka [45] and Chancharoenchai et al. [7] suggest that the money supply can be linked to stock prices through portfolio substitution or inflationary expectations. Portfolio theory suggests that an increase in money supply may induce asset managers to rebalance their holding. The nature of rebalancing, indeed, will depend on possible impact of money supply, both good and bad, on inflation, discount rate, corporate earnings and asset prices. Thus, we hypothesized that money supply maintains either positive or negative relationship with stock market activities.

The relationship between exchange rates and stock returns primarily depends on the nature of the economy. For the export dominated country the depreciation of domestic currency will have a favorable impact on the domestic stock market and vice versa [45] [46]. Again, the depreciation of domestic currency may also contribute to capital out-flows, increase in foreign liabilities, etc., which may ultimately slows down the economic and stock market activities. Hence, a negative relationship is expected [47]. On the other hand, an appreciation in the value of domestic currency may cause a decrease in stock prices for the companies under the export sector and an increase in stock prices for the companies under the import sector. It may also increases the pay-offs of the domestic assets held by foreigners in their own currencies. Thus, the theoretical explanations and empirical evidences on the relation between the exchange rates and asset prices fail to suggest any definite direction about the interdependence among the variables.

\section{Data and Time Period}

For our empirical investigation the data consist of Index of Industrial Production (IIP), Whole Sale Price Index (WPI), Money Supply (M3), Yields on 91-day Treasury Bills (YTB), Yields on Long-term (10-year) Government Bonds (YLGB), Competitiveness of Domestic Currency measured by the price of one US \$ expressed in terms of Rupee (EX) and the BSE SENSEX 30(Index) to represent Stock Market Prices.

Estimations based on the monthly data provide a short-run insight and at the same time capture more macro- 
economic relationship than the very high (daily) or low (yearly) frequency data [48]. Thus, we have used log-level monthly data series for all the variables under this study (except YTB and YLGB, see [26]) from January, 1991 to April, 2008. The basic data are collected from the various publications and the official web-sites of the Reserve Bank of India and the Bombay Stock Exchange.

\section{Empirical Methodology and Findings}

\subsection{Time Series Properties}

In our quest to search the dynamic relationship between the stock prices and the select macroeconomic variables, we have estimated the relationship by considering the model described in the Equation (1).

For this, we have examined, firstly, the order of integration of the time series at log-levels with "constant", and "constant and trend". In the literature of time series analysis, huge stock of unit root tests emerged during the past quarter century, but the certainty about inference is yet to be converged. There is ambiguity on what procedure of testing should be adopted and how much this procedure is reliable [49] [50]. Thus we relied, primarily, on the widely used ADF test [51] and then tested the series with the methodologies posited by Elliott, Rothenberg and Stock [52] (DF-GLS test) and Ng and Perron [53], using the lag order suggested by Schwarz [54]. All the variables under our study are found integrated of order one when we have used the "constant", and "constant and trend" at one percent level of significance (Tables 1-3).

In our next step, the optimum lag order is searched and selected by using the "information criteria" like: Akaike Information Criterion (AIC) [55], Schwarz Information Criterion (BIC) [54] and Hannan-Quinn Information Criterion (HQC) [56] in a VAR framework. Thus, we have obtained one lag order under BIC and HQC and two in AIC (see Table 4) as the optimum one. Bearing in mind the informational efficiency of stock markets, empirical studies generally prefer lower-order lags [57]-[59]. Thus, we have used lower-order lag length, i.e., one throughout our subsequent empirical analyses.

The number of significant cointegrating vectors and the deterministic component present in the cointegrating space are investigated simultaneously by using the maximum likelihood based $\lambda_{\max }$ and $\lambda_{\text {trace }}$ statistics suggested by Johansen [60] [61] and Johansen and Juselius [62] [63].

Table 1. ADF test for unit root.

\begin{tabular}{ccccccc}
\hline \multirow{2}{*}{ Variables } & \multicolumn{3}{c}{ With Constant } & \multicolumn{3}{c}{ With Constant and Trend } \\
\cline { 2 - 6 } & Lag Order (SIC) & t-statistic & p-value & Lag Order (SIC) & t-statistic & p-value \\
\hline LNINDEX & 0 & -1.248904 & 0.6531 & 0 & -1.970714 & 0.6134 \\
$\Delta($ LNINDEX) & 0 & $-13.34354^{*}$ & 0.0000 & 0 & $-13.30675^{*}$ & 0.0000 \\
YTB & 0 & -1.999862 & 0.2869 & 0 & -2.230400 & 0.4698 \\
$\Delta(Y T B)$ & 0 & $-14.17333^{*}$ & 0.0000 & 0 & $-14.16484^{*}$ & 0.0000 \\
YLGB & 0 & -0.714610 & 0.8395 & 0 & -1.983370 & 0.6066 \\
$\Delta($ YLGB $)$ & 0 & $-15.28190^{*}$ & 0.0000 & 0 & $-15.26461^{*}$ & 0.0000 \\
LNIIP & 12 & 1.810045 & 0.9998 & 8 & -2.745414 & 0.2197 \\
$\Delta(L N I I P)$ & 12 & $-3.499844^{*}$ & 0.0090 & 0 & $-23.74749^{*}$ & 0.0000 \\
LNWPI & 1 & -2.127308 & 0.2343 & 1 & -3.381787 & 0.0567 \\
$\Delta(L N W P I)$ & 0 & $-9.760308^{*}$ & 0.0000 & 0 & $-9.941319^{*}$ & 0.0000 \\
$L N M 3$ & 7 & 0.210015 & 0.9727 & 7 & -1.838127 & 0.6825 \\
$\Delta(L N M 3)$ & 6 & $-6.437581^{*}$ & 0.0000 & 6 & $-6.427127^{*}$ & 0.0000 \\
$L N E X$ & 6 & -2.249116 & 0.1898 & 0 & -2.992107 & 0.1370 \\
$\Delta(L N E X)$ & 6 & $-6.390432^{*}$ & 0.0000 & 0 & $-12.98763^{*}$ & 0.0000 \\
\hline
\end{tabular}

Note: 1) $\Delta$ Represents first difference of the respective variables. 2) SIC = Schwarz info criterion. 3) ${ }^{*}$ Indicates rejection of null hypothesis at one per cent level of significance. 
Table 2. DF-GLS test for unit root.

\begin{tabular}{|c|c|c|c|c|c|c|c|c|}
\hline \multirow{3}{*}{ Variables } & \multicolumn{4}{|c|}{ With Constant } & \multicolumn{4}{|c|}{ With Constant and Trend } \\
\hline & \multirow{2}{*}{ Lag Order (SIC) } & \multirow{2}{*}{ t-statistic } & \multicolumn{2}{|c|}{ Critical Values } & \multirow{2}{*}{ Lag Order (SIC) } & \multirow{2}{*}{ t-statistic } & \multicolumn{2}{|c|}{ Critical Values } \\
\hline & & & 1\% Level & $5 \%$ level & & & 1\% Level & $5 \%$ level \\
\hline LNINDEX & 0 & 1.484787 & -2.576181 & -1.942368 & 0 & -1.369645 & -3.460700 & -2.928600 \\
\hline$\Delta(L N I N D E X)$ & 0 & $-4.748853^{*}$ & -2.576236 & -1.942376 & 0 & $-7.938752^{*}$ & -3.460600 & -2.928800 \\
\hline YTB & 0 & -1.222985 & -2.576181 & -1.942368 & 0 & -1.530449 & -3.460700 & -2.928600 \\
\hline$\Delta(Y T B)$ & 0 & $-14.20656^{*}$ & -2.576236 & -1.942376 & 0 & $-14.19219^{*}$ & -3.460600 & -2.928800 \\
\hline$Y L G B$ & 0 & -0.587079 & -2.576181 & -1.942368 & 0 & -1.197840 & -3.460700 & -2.928600 \\
\hline$\Delta(Y L G B)$ & 0 & $-15.03603^{*}$ & -2.576236 & -1.942376 & 0 & $-15.06741^{*}$ & -3.460600 & -2.928800 \\
\hline LNIIP & 1 & 0.962474 & -2.576236 & -1.942376 & 6 & -2.411969 & -3.460100 & -2.929800 \\
\hline$\Delta(L N I I P)$ & 0 & $-18.88641^{*}$ & -2.576236 & -1.942376 & 0 & $-21.39881^{*}$ & -3.460600 & -2.928800 \\
\hline$L N W P I$ & 1 & 3.787782 & -2.576236 & -1.942376 & 1 & -0.891945 & -3.460600 & -2.928800 \\
\hline$\Delta(L N W P I)$ & 1 & $-5.664724^{*}$ & -2.576291 & -1.942383 & 0 & $-9.486901^{*}$ & -3.460600 & -2.928800 \\
\hline LNM3 & 12 & 1.450350 & -2.576875 & -1.942465 & 7 & -1.589786 & -3.460000 & -2.930000 \\
\hline$\Delta(L N M 3)$ & 6 & $-4.061763^{*}$ & -2.576576 & -1.942423 & 6 & $-5.125533^{*}$ & -3.460000 & -2.930000 \\
\hline LNEX & 0 & 0.823061 & -2.576181 & -1.942368 & 0 & -0.151089 & -3.460700 & -2.928600 \\
\hline$\Delta(L N E X)$ & 2 & $-3.363098^{*}$ & -2.576347 & -1.942391 & 2 & $-5.682624^{*}$ & -3.460400 & -2.929200 \\
\hline
\end{tabular}

Note: 1) $\Delta$ Represents first difference of the respective variables. 2) ${ }^{*}$ Indicates rejection of $\mathrm{H}_{0}$ at the one per cent level. 3) SIC = Schwarz info criterion.

Table 3. Ng-Perron test for unit root.

\begin{tabular}{|c|c|c|c|c|c|c|c|c|c|c|}
\hline \multicolumn{11}{|c|}{ Observed Test Statistics } \\
\hline \multirow{2}{*}{ Variables } & \multicolumn{5}{|c|}{ With Constant } & \multicolumn{5}{|c|}{ With Constant and Trend } \\
\hline & $\operatorname{Lag}^{@}$ & MZa & MZt & MSB & MPT & $\operatorname{Lag}^{@}$ & MZa & MZt & MSB & MPT \\
\hline LNINDEX & 0 & 1.51749 & 1.53486 & 1.01145 & 78.7242 & 0 & -3.78357 & -1.34717 & 0.35606 & 23.6918 \\
\hline$\Delta(L N I N D E X)$ & 0 & $-36.8049^{*}$ & $-4.28489^{*}$ & $0.11642^{*}$ & $0.68011^{*}$ & 0 & $-74.3489^{*}$ & $-6.06988^{*}$ & $0.08164^{*}$ & $1.34323^{*}$ \\
\hline YTB & 0 & -3.12373 & -1.20962 & 0.38724 & 7.78780 & 0 & -4.54802 & -1.50479 & 0.33087 & 20.0125 \\
\hline$\Delta(Y T B)$ & 0 & $-102.994^{*}$ & $-7.17466^{*}$ & $0.06966^{*}$ & $0.24065^{*}$ & 0 & $-102.992^{*}$ & $-7.17495^{*}$ & $0.06966^{*}$ & $0.88905^{*}$ \\
\hline$Y L G B$ & 0 & -1.00789 & -0.58521 & 0.58063 & 18.7517 & 0 & -2.77695 & -1.17538 & 0.42326 & 32.7225 \\
\hline$\Delta(Y L G B)$ & 0 & $-102.728^{*}$ & $-7.14901^{*}$ & $0.06959^{*}$ & $0.27197^{*}$ & 0 & $-102.705^{*}$ & $-7.14880^{*}$ & $0.06960^{*}$ & $0.95249^{*}$ \\
\hline LNIIP & 1 & 1.13225 & 0.86864 & 0.76718 & 45.0911 & 8 & -3.08920 & -1.18350 & 0.38311 & 28.0940 \\
\hline$\Delta(L N I I P)$ & 1 & $-63.1585^{*}$ & $-5.58140^{*}$ & $0.08837^{*}$ & $0.47690^{*}$ & 2 & $-29.6087^{*}$ & $-3.76963^{*}$ & $0.12732^{*}$ & $3.53329^{*}$ \\
\hline LNWPI & 1 & 1.46557 & 4.34899 & 2.96745 & 618.255 & 1 & -1.69767 & -0.86747 & 0.51098 & 49.2228 \\
\hline$\Delta(L N W P I)$ & 1 & $-51.2310^{*}$ & $-5.06080^{*}$ & $0.09878^{*}$ & $0.47918^{*}$ & 0 & $-87.5789^{*}$ & $-6.59348^{*}$ & $0.07529^{*}$ & $1.13694^{*}$ \\
\hline LNM3 & 12 & 1.43682 & 1.72678 & 1.20181 & 106.654 & 7 & -6.04953 & -1.64959 & 0.27268 & 14.9996 \\
\hline$\Delta(L N M 3)$ & 6 & $-17.9833^{*}$ & $-2.94851^{*}$ & $0.16396^{*}$ & $1.54807^{*}$ & 6 & $-76.2112^{*}$ & $-6.16768^{*}$ & $0.08093^{*}$ & $1.21837^{*}$ \\
\hline$L N E X$ & 0 & 0.47707 & 0.89139 & 1.86845 & 201.236 & 0 & -0.14544 & -0.09366 & 0.64400 & 88.2744 \\
\hline$\Delta(L N E X)$ & 2 & $-18.3840^{*}$ & $-3.00717^{*}$ & $0.16358^{*}$ & $1.42395^{*}$ & 2 & $-46.1237^{*}$ & $-4.68291^{*}$ & $0.10153^{*}$ & $2.58710^{*}$ \\
\hline \multicolumn{11}{|c|}{ CRITICAL VALUES^ } \\
\hline & & \multicolumn{4}{|c|}{ Constant } & \multicolumn{5}{|c|}{ Constant and Trend } \\
\hline 1\% Level & & -13.8000 & -2.58000 & 0.17400 & 1.78000 & & 23.8000 & -3.42000 & 0.14300 & 4.03000 \\
\hline 5\% Level & & -8.10000 & -1.98000 & 0.23300 & 3.17000 & & 17.3000 & -2.91000 & 0.16800 & 5.48000 \\
\hline $10 \%$ Level & & -5.70000 & -1.62000 & 0.27500 & 4.45000 & & 14.2000 & -2.62000 & 0.18500 & 6.67000 \\
\hline
\end{tabular}

Note: 1) $\Delta$ Represents first difference of the respective variable; 2) @ Indicates Spectral GLS-detrended AR based on SIC; 3)^ represents Ng-Perron (2001, Table 1); 4) ${ }^{*}$ Rejects the Null at one per cent level of significance. 
Table 4. Test for maximum lag order at log level.

\begin{tabular}{cccc}
\hline \multicolumn{4}{c}{ Variables: lnINDEX, YTB, YLGB, lnIIP, lnWPI, lnM3, lnEX } \\
\hline lags & AIC & BIC & HQC \\
\hline 1 & -21.59646 & $-20.79672^{*}$ & $-21.27292^{*}$ \\
2 & $-21.70781^{*}$ & -20.10833 & -21.06073 \\
3 & -21.55318 & -19.15396 & -20.58255 \\
4 & -21.64450 & -18.44554 & -20.35033 \\
5 & -21.55933 & -17.56063 & -19.94162 \\
\hline
\end{tabular}

Note: 1 ) ${ }^{*}$ Indicate the best (that is, minimized) values of the respective information criteria, AIC = Akaikecriterion, BIC = Schwartz Bayesian criterion and HQC = Hannan-Quinn criterion; 2) VAR Lag Order: AIC = 2, BIC = 1, HQC = 1 .

Following Engle and Granger, [64] under some regulatory conditions one can write a cointegrated process of $y_{t}$ in a Vector error Correction Model below:

$$
\Delta y_{t}=m_{o}+\Gamma_{1} \Delta y_{t-1+} \Gamma_{2} \Delta y_{t-2}+\cdots+\Gamma_{p-1} \Delta y_{t-(p-1)}+\Pi y_{t-1}+\varepsilon_{t}
$$

where $\Delta$ stands for first difference, $\mu_{0}$ includes deterministic components (non-seasonal), $y_{t}$ is a $p x 1$ vector ( here, $p=7$ for our study), $\Gamma$ and $\Pi$ are coefficient-matrices representing short and long-term impacts, respectively and $\varepsilon_{\mathrm{t}}$ is residual vector assumed to be independent and identically distributed as multi-normal distribution with mean zero and variance $\Omega$. Johansen [60] [61] decomposes $\Pi$ in to two matrices $\alpha$ and $\beta$, both of which are p x r matrices $(r<p)$ such that $\Pi=\alpha \beta^{\prime}$. Thus, the rows of $\beta$ may be defined as the $\mathrm{r}$ distinct cointegrating vectors. Then a valid cointegrating vector will be given by the corresponding eigenvalue [61]. Here, $\alpha$ and $\beta$ are pxr matrices and denote the loading and the cointegrating space with order $r$, respectively.

Johansen proposes a "Trace test" for determining the cointegrating rank " $r$ " such that:

$$
\lambda_{\text {trace }}=-T \sum_{i=r+1}^{k} \operatorname{In}\left(1-\lambda_{i}\right)
$$

and a likelihood ratio test to assess whether there is a maximum number of cointegrating vectors against $r+1$ such that:

$$
\lambda_{\max }(r, r+1)=-T \operatorname{In}\left(\hat{1-\lambda_{i}}\right)
$$

with critical values given in Johansen [61].

Since $\lambda_{\text {trace }}$ statistic takes into account all $(n-r)$ of the smallest eigenvalues, it tends to have more power than the $\lambda_{\max }$ statistic [4] [65] [66]. In the cases where a conflict between these two test statistics occurs, Johansen and Juselius [62] suggested to use the $\lambda_{\text {trace }}$ statistic. Moreover, we have estimated three models to ascertain the deterministic component present in the cointegrating space of the variables under our study. The models are: 1) where there is no data trend at level, and intercept with no trend is present in the cointegrating space of the variables (M-1), 2) where there is a linear trend at level, and intercept with no trend is present in the cointegrating space of the variables (M-2), and 3) where there is a linear trend at level, and intercept with trend is present in the cointegrating space of the variables (M-3). The search procedure runs from the most restricted form to the least one. In our seven-variable system, constant (linear trend) (see Table 5) and two cointegrating ranks are obtained in the cointegrating relationships (see Table 6).

\subsection{The Relationship}

Johansen and Juselius [62] [63] have noted that the first cointegrating vector corresponding to the highest eigenvalue is most correlated with the stationarity part of the model, hence we have followed this to report the cointegrating vector. After normalizing the stock price indices to one, the long-term relationship between stock prices and macroeconomic variables corresponding to the highest eigenvalue at the optimum lag order with one cointegrating rank is: 
Table 5. Deterministic component in the cointegrating relationship.

\begin{tabular}{cccccccccc}
\hline & \multicolumn{3}{c}{ Model-1 } & \multicolumn{3}{c}{ Model-2 } & \multicolumn{3}{c}{ Model-3 } \\
\cline { 2 - 6 } Null(Alt) & Eigenvalue & $\begin{array}{c}\text { Trace } \\
\text { Statistic }\end{array}$ & $\begin{array}{c}5 \% \text { Critical } \\
\text { Value }\end{array}$ & Eigenvalue & $\begin{array}{c}\text { Trace } \\
\text { Statistic }\end{array}$ & $\begin{array}{c}5 \% \text { Critical } \\
\text { Value }\end{array}$ & Eigenvalue & $\begin{array}{c}\text { Trace } \\
\text { Statistic }\end{array}$ & $\begin{array}{c}5 \% \text { Critical } \\
\text { Value }\end{array}$ \\
\hline $\mathrm{r}=0$ & 0.764904 & $496.3475^{*}$ & 134.6780 & 0.402015 & $222.6409^{*}$ & 125.6154 & 0.405226 & $244.7408^{*}$ & 150.5585 \\
$\mathrm{r} \leq 1(\mathrm{r}>1)$ & 0.395373 & $196.6610^{*}$ & 103.8473 & 0.240651 & $116.2038^{*}$ & 95.75366 & 0.240690 & $137.1889^{*}$ & 117.7082 \\
$\mathrm{r} \leq 2(\mathrm{r}>2)$ & 0.205546 & $92.51021^{*}$ & 76.97277 & 0.139537 & 59.2180 & 69.81889 & 0.141687 & 80.19231 & 88.80380 \\
$\mathrm{r} \leq 3(\mathrm{r}>3)$ & 0.098314 & 44.87945 & 54.07904 & 0.058952 & 28.10901 & 47.85613 & 0.101748 & 48.56553 & 63.87610 \\
$\mathrm{r} \leq 4(\mathrm{r}>4)$ & 0.048978 & 23.45728 & 35.19275 & 0.047468 & 15.53149 & 29.79707 & 0.057380 & 26.35352 & 42.91525 \\
$\mathrm{r} \leq 5(\mathrm{r}>5)$ & 0.043859 & 13.06214 & 20.26184 & 0.019862 & 5.464742 & 15.49471 & 0.047422 & 14.12144 & 25.87211 \\
$\mathrm{r} \leq 6(\mathrm{r}>6)$ & 0.018086 & 3.778176 & 9.164546 & 0.006317 & 1.311845 & 3.841466 & 0.019444 & 4.064625 & 12.51798 \\
\hline
\end{tabular}

Note: 1) Model-1 represents no deterministic trend with restricted constant, Model-2 represents Linear Deterministic trend with restricted constant and Model-3 represents Linear Deterministic Trend (Restricted); 2) ${ }^{*}$ Denotes rejection of the null hypothesis at $5 \%$ Level.

Table 6. Cointegrating ranks of the macroeconomic variables.

\begin{tabular}{|c|c|c|c|c|c|c|c|c|}
\hline Hypothesized & & Trace & 0.05 & & & Max-Eigen & 0.05 & \\
\hline No. of CE(s) & Eigenvalue & Statistic & Critical Value & Prob. & Eigenvalue & Statistic & Critical Value & Prob. \\
\hline None* & 0.402015 & 222.6409 & 125.6154 & 0.0000 & 0.402015 & 106.4371 & 46.23142 & 0.0000 \\
\hline At most $1^{*}$ & 0.240651 & 116.2038 & 95.75366 & 0.0010 & 0.240651 & 56.98576 & 40.07757 & 0.0003 \\
\hline At most 2 & 0.139537 & 59.21803 & 69.81889 & 0.2602 & 0.139537 & 31.10902 & 33.87687 & 0.1033 \\
\hline At most 3 & 0.058952 & 28.10901 & 47.85613 & 0.8090 & 0.058952 & 12.57752 & 27.58434 & 0.9070 \\
\hline At most 4 & 0.047468 & 15.53149 & 29.79707 & 0.7447 & 0.047468 & 10.06675 & 21.13162 & 0.7384 \\
\hline At most 5 & 0.019862 & 5.464742 & 15.49471 & 0.7577 & 0.019862 & 4.152897 & 14.26460 & 0.8429 \\
\hline At most 6 & 0.006317 & 1.311845 & 3.841466 & 0.2521 & 0.006317 & 1.311845 & 3.841466 & 0.2521 \\
\hline
\end{tabular}

Note: *Denotes rejection of the null hypothesis at the $5 \%$ level.

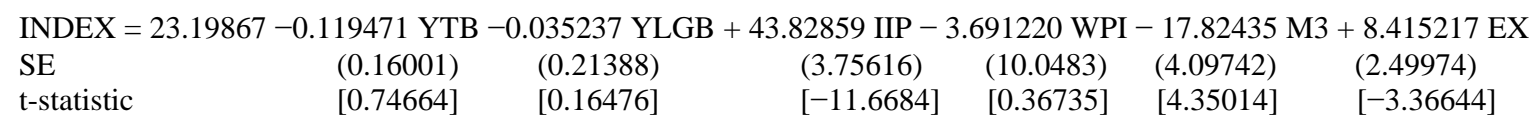

The short term adjustment coefficient of the stock market is (-) 0.002182 with SE and t-statistic equals to 0.00232, and 1.28655 respectively. The Portmanteau Test statistics attest the presence of no auto-correlation in the residuals of the above long-term relation (see Table 7).

As proposed by Johansen [60], the likelihood ratio test is carried on to assess the significance of the variables individually and on the basis of the homogeneous economic segments they belong to, that is, money supply and interests (which is represented by YTB, YLGB and M3), goods market (IIP and WPI) and exchange market (EX). The results indicate that all the variables when tested under different homogeneous economic segments or markets are statistically significantly belong to the co-integrating space. When the variables are restricted and tested individually, we find, only the output, money supply and exchange rates are statistically and significantly forming the core of the long-term relationship with the stock market (see Table 8). Our observation also suggests that the index for industrial production, money supply and exchange rate are the major long-term determinants of the Indian asset market; the segments of the Indian economy under the study i.e., bond market and monetary base, output market and foreign exchange markets are integrated with the stock market. Hence the traits in one market are expected to be estimated and explained well by the activities of the other markets.

The findings of this study are consistent with the macroeconomic theories and the empirical works carried on by several scholars [2] [3] [5] [9] [12] [18] [28] [32] [42] [67]. 
Table 7. Residual portmanteau tests for autocorrelations.

\begin{tabular}{cccccc}
\hline Lags & Q-Stat & p-value & Adj Q-Stat & p-value & df \\
\hline 1 & 98.87615 & NA & 99.35613 & NA & NA \\
2 & 163.7131 & 0.0833 & 164.8257 & 0.0745 & 140 \\
\hline
\end{tabular}

Table 8. Likelihood ratio test statistics to test the restrictions in the cointegrating vectors.

\begin{tabular}{lcc}
\hline & Variables/segments & Probability-value \\
\hline INDEX & 0.558827 & 0.454733 \\
YTB & 0.473982 & 0.491161 \\
YLGB & 0.015791 & 0.899999 \\
IIP & 49.28870 & 0.00000 \\
WPI & 0.099900 & 0.751950 \\
M3 & 12.25613 & 0.000464 \\
EX & 4.855293 & 0.027561 \\
Money supply and Interests (YTB, YLGB and M3) & 19.66450 & 0.000199 \\
Commodity market variables (IIP and WPI) & 53.98645 & 0.000000 \\
Exchange market variable (EX) & 4.855293 & 0.027561 \\
\hline
\end{tabular}

The negative relationship between long-term interest rate and stock price virtually negates the arguments of neo-liberalists who theorized higher interest rate (equilibrium) attracts more savings thus investment grows that allows investors to earn more return in the market. The negative coefficient of short term interest rate is very much consistent to the finance and economic theories. The negative relationship between the short term interest rates and stock market is reported by many scholars like, Bulmash and Trivoli [15] in the case of the United States, Wangbangpo and Sharma [4] for Philippines, Singapore and Thailand, Adjasi, et al. [68] for Ghana, Mukherjee and Naka [45] and Maysami and Koh [69] for Japan.

Inflation and stock price is negatively related in our study. The finding is consistent with finance theory but contradicts the experiences of developed economies [35] [37] etc. It is worthwhile to mention that both money supply and inflation, the two variables that are closely intertwined with one another, show the same pattern, i.e., negative relationship with asset price. Presumably, belying the hope of the no-classical theorists, money supply is contributing in inflation and adversely affecting the functioning of stock market.

The positive relationship between the exchange rate (EX) and asset prices indicates the dominance and anchoring of the export oriented companies in the Indian stock markets. The evidences from the markets like Japan [45], Indonesia, Malaysia, Philippines [4], India [70] [71], Fiji [72] and many others attest our finding. Our observation also supports the popular belief that flow of foreign fund in Indian economy boosts up economic activities and asset price. The flow of fund has a spiraling effect. The increasing trend in capital-inflows coupled with the depreciation of domestic currency offers an excellent opportunity to global investors to maximize their return by investing in India that adds vigor to capital market [73].

\subsection{The Causal Relationship}

We have estimated the Granger causal relationship between the variables within the framework of vector error correction model using the optimum lag order, the deterministic component and one cointegrating relationship.

Firstly, we hypothesized to investigate prima facie causality between stock market vis-à-vis the select macroeconomic variables in a bivariate setting. Testing for prima facie causality is considered by the scholars as the first major step towards concluding causality between two variables in presence of other variables [67]. We have found that the prima facie causality runs only from stock market (Index) to output (IIP) (see Table 9). 
Table 9. Causal-relationship between the macroeconomic variables and stock returns.

\begin{tabular}{|c|c|c|}
\hline Null Hypothesis $\left(\mathrm{H}_{0}\right)$ & F-Statistic & p-value \\
\hline lnIndex “do not Granger causes” lnYTB & 0.9448 & 0.3896 \\
\hline lnYTB “do not Granger causes” lnIndex & 1.5980 & 0.2036 \\
\hline lnIndex “do not Granger causes” InYLGB & 0.6393 & 0.5282 \\
\hline lnYLGB “do not Granger causes” lnIndex & 0.7637 & 0.4666 \\
\hline InIndex “do not Granger causes” ln IIP & 5.8643 & 0.0031 \\
\hline In IIP “do not Granger causes” InIndex & 1.7701 & 0.1717 \\
\hline lnIndex “do not Granger causes” lnWPI & 1.4914 & 0.2263 \\
\hline ln WPI “do not Granger causes” InIndex & 0.9979 & 0.3696 \\
\hline lnIndex “do not Granger causes” lnM3 & 0.7399 & 0.4778 \\
\hline ln M3 “do not Granger causes” InIndex & 0.1510 & 0.9850 \\
\hline InIndex “do not Granger causes” ln EX & 1.2371 & 0.2913 \\
\hline In EX “do not Granger causes” InIndex & 0.3013 & 0.7400 \\
\hline InIndex “do not Granger causes” All Variables & 2.4241 & 0.0041 \\
\hline All Variables “do not Granger cause” InIndex & 1.6338 & 0.0764 \\
\hline
\end{tabular}

Next, we hypothesized to test whether the select macroeconomic variables jointly can predict the movements in stock market and vice versa. We observed that there exists a bi-directional causality between the stock market and the select macroeconomic variables at less than ten percent level of significance (see Table 9). It indicates that the stock prices are the functions of the past and current values of the economic activities measured by the select variables under the study. Alternatively, the reverse casual relation suggests that past values of the stock price variations can be perceived as a good indicator for their macroeconomic performances as a whole. In a more stringent level of significance (i.e., less than one percent), stock market activities lead the economic activities and not the vice versa. Grossly, it indicates that in the "new regime" the growth of Indian industrial economy depends on the growth of capital market. The experience suggests that Fry [23] and others are correct in adoring the role of the market in economic development.

\subsection{The Innovation Analysis}

Unlike the Granger causality test, the Impulse Response Analysis provides a quantitative idea about the potential responses of the variables against the innovations on themselves and the others. If we assume that the equation system of a time series $\mathrm{y}_{\mathrm{t}}$ is stable, then the equilibrium is found by obtaining the final form of the system. By using lag operator and stability condition, one can write the form as:

$$
y_{t}=\hat{y}+v_{t}+\Gamma v_{t-1}+\Gamma^{2} v_{t-2}+\cdots
$$

where, $\mathrm{v}_{\mathrm{t}}$ is the error term. From the equation (Equation (6)), we can say, $\mathrm{y}_{\mathrm{t}}$ would reach its equilibrium position $\hat{y}$, if $v_{t}, v_{t-1}, v_{t-2}$ equals to zero. Now, if we inject a shock to the system by changing one of the $v^{\prime} s$ in the above equation, for one period, and then returning it to zero thereafter, then we will see $y_{\mathrm{mt}}$ will move away from, then return to its equilibrium. The impulse response of the system is the path whereby the variable $\mathrm{m}$ (i.e., $\mathrm{y}_{\mathrm{mt}}$ ) returns to the equilibrium position [74].

As the responses to innovations are likely to be sensitive to the ordering of the variables, we have followed the suggestion of [75] and arranged the variables as follows: Index, YTB, YLGB, IIP, WPI, M3 and EX. The Impulse Response Analysis is carried on for a horizon of ten months. We have estimated the responses of stock prices to "one standard deviation shock" of macroeconomic variables and vice versa with all significant cointegrating ranks to check the robustness of the observations obtained from Granger causality test. 
The Indian asset prices are observed to be sensitive more to their own innovations. The impacts of the "one standard deviation shock" in stock prices to the market itself are almost flat over the horizon of 10 months. A close scrutiny of the responses indicates that the market has the potentiality to be more efficient in the future. Strictly, the next best substantial response of the macroeconomic variables to the Indian stock market is the IIP followed by the exchange and the rest others. The impacts of the "shock" in IIP, M3, and WPI individually on the stock prices are marginal (see Table 10). It confirms the results obtained from the prima facie Granger causality which runs from the stock prices to IIP and suggests that the market satisfies the condition of weak form of efficiency.

Table 10. Impulse response analysis.

\begin{tabular}{|c|c|c|c|c|c|c|c|}
\hline \multicolumn{8}{|c|}{ Response of LNINDEX: } \\
\hline Period & LNINDEX & YTB & YLGB & LNIIP & LNWPI & LNM3 & LNEX \\
\hline 1 & 0.085652 & 0.000000 & 0.000000 & 0.000000 & 0.000000 & 0.000000 & 0.000000 \\
\hline 2 & 0.085510 & -0.000198 & -0.000161 & 0.005753 & $2.52 \mathrm{E}-05$ & -0.000159 & 0.000405 \\
\hline 3 & 0.085462 & -0.000263 & -0.000213 & 0.007648 & $3.36 \mathrm{E}-05$ & -0.000211 & 0.000538 \\
\hline 4 & 0.085447 & -0.000284 & -0.000231 & 0.008273 & $3.63 \mathrm{E}-05$ & -0.000229 & 0.000582 \\
\hline 5 & 0.085442 & -0.000291 & -0.000237 & 0.008479 & $3.72 \mathrm{E}-05$ & -0.000234 & 0.000597 \\
\hline 6 & 0.085440 & -0.000294 & -0.000238 & 0.008546 & $3.75 \mathrm{E}-05$ & -0.000236 & 0.000601 \\
\hline 7 & 0.085440 & -0.000294 & -0.000239 & 0.008569 & $3.76 \mathrm{E}-05$ & -0.000237 & 0.000603 \\
\hline 8 & 0.085439 & -0.000295 & -0.000239 & 0.008576 & $3.76 \mathrm{E}-05$ & -0.000237 & 0.000604 \\
\hline 9 & 0.085439 & -0.000295 & -0.000239 & 0.008578 & $3.77 \mathrm{E}-05$ & -0.000237 & 0.000604 \\
\hline 10 & 0.085439 & -0.000295 & -0.000239 & 0.008579 & $3.77 \mathrm{E}-05$ & -0.000237 & 0.000604 \\
\hline \multicolumn{8}{|c|}{ Response of YTB: } \\
\hline Period & LNINDEX & YTB & YLGB & LNIIP & LNWPI & LNM3 & LNEX \\
\hline 1 & 0.000000 & 0.573015 & 0.000000 & 0.000000 & 0.000000 & 0.000000 & 0.000000 \\
\hline 2 & 0.001617 & 0.575252 & 0.001817 & -0.065114 & -0.000286 & 0.001799 & -0.004582 \\
\hline 3 & 0.002149 & 0.575988 & 0.002415 & -0.086567 & -0.000380 & 0.002392 & -0.006092 \\
\hline 4 & 0.002325 & 0.576231 & 0.002613 & -0.093636 & -0.000411 & 0.002587 & -0.006589 \\
\hline 5 & 0.002383 & 0.576311 & 0.002678 & -0.095965 & -0.000421 & 0.002651 & -0.006753 \\
\hline 6 & 0.002402 & 0.576338 & 0.002699 & -0.096732 & -0.000425 & 0.002673 & -0.006807 \\
\hline 7 & 0.002408 & 0.576346 & 0.002706 & -0.096985 & -0.000426 & 0.002680 & -0.006825 \\
\hline 8 & 0.002410 & 0.576349 & 0.002708 & -0.097068 & -0.000426 & 0.002682 & -0.006831 \\
\hline 9 & 0.002411 & 0.576350 & 0.002709 & -0.097095 & -0.000426 & 0.002683 & -0.006833 \\
\hline 10 & 0.002411 & 0.576350 & 0.002709 & -0.097104 & -0.000426 & 0.002683 & -0.006833 \\
\hline \multicolumn{8}{|c|}{ Response of YLGB: } \\
\hline Period & LNINDEX & YTB & YLGB & LNIIP & LNWPI & LNM3 & LNEX \\
\hline 1 & 0.000000 & 0.000000 & 0.343770 & 0.000000 & 0.000000 & 0.000000 & 0.000000 \\
\hline 2 & -0.000564 & -0.000780 & 0.343137 & 0.022698 & $9.96 \mathrm{E}-05$ & -0.000627 & 0.001597 \\
\hline 3 & -0.000749 & -0.001036 & 0.342928 & 0.030176 & 0.000132 & -0.000834 & 0.002124 \\
\hline 4 & -0.000810 & -0.001121 & 0.342860 & 0.032640 & 0.000143 & -0.000902 & 0.002297 \\
\hline 5 & -0.000831 & -0.001149 & 0.342837 & 0.033452 & 0.000147 & -0.000924 & 0.002354 \\
\hline 6 & -0.000837 & -0.001158 & 0.342829 & 0.033719 & 0.000148 & -0.000932 & 0.002373 \\
\hline 7 & -0.000839 & -0.001161 & 0.342827 & 0.033807 & 0.000148 & -0.000934 & 0.002379 \\
\hline 8 & -0.000840 & -0.001162 & 0.342826 & 0.033836 & 0.000149 & -0.000935 & 0.002381 \\
\hline 9 & -0.000840 & -0.001162 & 0.342826 & 0.033846 & 0.000149 & -0.000935 & 0.002382 \\
\hline 10 & -0.000840 & -0.001162 & 0.342826 & 0.033849 & 0.000149 & -0.000935 & 0.002382 \\
\hline
\end{tabular}




\section{Continued}

\begin{tabular}{|c|c|c|c|c|c|c|c|}
\hline \multicolumn{8}{|c|}{ Response of LNIIP: } \\
\hline Period & LNINDEX & YTB & YLGB & LNIIP & LNWPI & LNM3 & LNEX \\
\hline 1 & 0.000000 & 0.000000 & 0.000000 & 0.053782 & 0.000000 & 0.000000 & 0.000000 \\
\hline 2 & 0.000880 & 0.001217 & 0.000989 & 0.018332 & -0.000156 & 0.000979 & -0.002495 \\
\hline 3 & 0.001170 & 0.001619 & 0.001315 & 0.006652 & -0.000207 & 0.001302 & -0.003317 \\
\hline 4 & 0.001266 & 0.001751 & 0.001422 & 0.002804 & -0.000224 & 0.001408 & -0.003587 \\
\hline 5 & 0.001297 & 0.001794 & 0.001458 & 0.001536 & -0.000229 & 0.001444 & -0.003677 \\
\hline 6 & 0.001307 & 0.001809 & 0.001469 & 0.001118 & -0.000231 & 0.001455 & -0.003706 \\
\hline 7 & 0.001311 & 0.001813 & 0.001473 & 0.000981 & -0.000232 & 0.001459 & -0.003716 \\
\hline 8 & 0.001312 & 0.001815 & 0.001475 & 0.000935 & -0.000232 & 0.001460 & -0.003719 \\
\hline 9 & 0.001312 & 0.001815 & 0.001475 & 0.000920 & -0.000232 & 0.001461 & -0.003720 \\
\hline 10 & 0.001313 & 0.001816 & 0.001475 & 0.000915 & -0.000232 & 0.001461 & -0.003720 \\
\hline \multicolumn{8}{|c|}{ Response of LNWPI: } \\
\hline Period & LNINDEX & YTB & YLGB & LNIIP & LNWPI & LNM3 & LNEX \\
\hline 1 & 0.000000 & 0.000000 & 0.000000 & 0.000000 & 0.006114 & 0.000000 & 0.000000 \\
\hline 2 & $-1.54 \mathrm{E}-06$ & $-2.13 E-06$ & $-1.73 E-06$ & $6.21 \mathrm{E}-05$ & 0.006115 & $-1.72 \mathrm{E}-06$ & $4.37 \mathrm{E}-06$ \\
\hline 3 & $-2.05 \mathrm{E}-06$ & $-2.84 \mathrm{E}-06$ & $-2.31 \mathrm{E}-06$ & $8.26 \mathrm{E}-05$ & 0.006115 & $-2.28 \mathrm{E}-06$ & $5.81 \mathrm{E}-06$ \\
\hline 4 & $-2.22 \mathrm{E}-06$ & $-3.07 \mathrm{E}-06$ & $-2.49 \mathrm{E}-06$ & $8.94 \mathrm{E}-05$ & 0.006115 & $-2.47 \mathrm{E}-06$ & $6.29 \mathrm{E}-06$ \\
\hline 5 & $-2.27 \mathrm{E}-06$ & $-3.15 E-06$ & $-2.56 \mathrm{E}-06$ & $9.16 \mathrm{E}-05$ & 0.006115 & $-2.53 \mathrm{E}-06$ & $6.44 \mathrm{E}-06$ \\
\hline 6 & $-2.29 \mathrm{E}-06$ & $-3.17 \mathrm{E}-06$ & $-2.58 \mathrm{E}-06$ & $9.23 \mathrm{E}-05$ & 0.006115 & $-2.55 \mathrm{E}-06$ & $6.50 \mathrm{E}-06$ \\
\hline 7 & $-2.30 \mathrm{E}-06$ & $-3.18 E-06$ & $-2.58 \mathrm{E}-06$ & $9.26 \mathrm{E}-05$ & 0.006115 & $-2.56 \mathrm{E}-06$ & $6.51 \mathrm{E}-06$ \\
\hline 8 & $-2.30 \mathrm{E}-06$ & $-3.18 \mathrm{E}-06$ & $-2.58 \mathrm{E}-06$ & $9.26 \mathrm{E}-05$ & 0.006115 & $-2.56 \mathrm{E}-06$ & $6.52 \mathrm{E}-06$ \\
\hline 9 & $-2.30 \mathrm{E}-06$ & $-3.18 \mathrm{E}-06$ & $-2.59 \mathrm{E}-06$ & $9.27 \mathrm{E}-05$ & 0.006115 & $-2.56 \mathrm{E}-06$ & $6.52 \mathrm{E}-06$ \\
\hline 10 & $-2.30 \mathrm{E}-06$ & $-3.18 \mathrm{E}-06$ & $-2.59 \mathrm{E}-06$ & $9.27 \mathrm{E}-05$ & 0.006115 & $-2.56 \mathrm{E}-06$ & $6.52 \mathrm{E}-06$ \\
\hline \multicolumn{8}{|c|}{ Response of LNM3: } \\
\hline Period & LNINDEX & YTB & YLGB & LNIIP & LNWPI & LNM3 & LNEX \\
\hline 1 & 0.000000 & 0.000000 & 0.000000 & 0.000000 & 0.000000 & 0.010146 & 0.000000 \\
\hline 2 & $-7.00 \mathrm{E}-05$ & $-9.68 \mathrm{E}-05$ & $-7.87 \mathrm{E}-05$ & 0.002820 & $1.24 \mathrm{E}-05$ & 0.010068 & 0.000198 \\
\hline 3 & $-9.31 \mathrm{E}-05$ & -0.000129 & -0.000105 & 0.003748 & $1.65 \mathrm{E}-05$ & 0.010042 & 0.000264 \\
\hline 4 & -0.000101 & -0.000139 & -0.000113 & 0.004055 & $1.78 \mathrm{E}-05$ & 0.010034 & 0.000285 \\
\hline 5 & -0.000103 & -0.000143 & -0.000116 & 0.004155 & $1.82 \mathrm{E}-05$ & 0.010031 & 0.000292 \\
\hline 6 & -0.000104 & -0.000144 & -0.000117 & 0.004189 & $1.84 \mathrm{E}-05$ & 0.010030 & 0.000295 \\
\hline 7 & -0.000104 & -0.000144 & -0.000117 & 0.004200 & $1.84 \mathrm{E}-05$ & 0.010030 & 0.000296 \\
\hline 8 & -0.000104 & -0.000144 & -0.000117 & 0.004203 & $1.84 \mathrm{E}-05$ & 0.010030 & 0.000296 \\
\hline 9 & -0.000104 & -0.000144 & -0.000117 & 0.004204 & $1.85 \mathrm{E}-05$ & 0.010030 & 0.000296 \\
\hline 10 & -0.000104 & -0.000144 & -0.000117 & 0.004205 & $1.85 \mathrm{E}-05$ & 0.010030 & 0.000296 \\
\hline \multicolumn{8}{|c|}{ Response of LNEX: } \\
\hline Period & LNINDEX & YTB & YLGB & LNIIP & LNWPI & LNM3 & LNEX \\
\hline 1 & 0.000000 & 0.000000 & 0.000000 & 0.000000 & 0.000000 & 0.000000 & 0.022544 \\
\hline 2 & $3.29 \mathrm{E}-05$ & $4.56 \mathrm{E}-05$ & $3.70 \mathrm{E}-05$ & -0.001327 & $-5.82 \mathrm{E}-06$ & $3.67 \mathrm{E}-05$ & 0.022451 \\
\hline 3 & $4.38 \mathrm{E}-05$ & $6.06 \mathrm{E}-05$ & $4.92 \mathrm{E}-05$ & -0.001764 & $-7.74 \mathrm{E}-06$ & $4.87 \mathrm{E}-05$ & 0.022420 \\
\hline 4 & $4.74 \mathrm{E}-05$ & $6.55 \mathrm{E}-05$ & $5.32 \mathrm{E}-05$ & -0.001908 & $-8.37 \mathrm{E}-06$ & $5.27 \mathrm{E}-05$ & 0.022410 \\
\hline 5 & $4.85 \mathrm{E}-05$ & $6.71 \mathrm{E}-05$ & $5.45 \mathrm{E}-05$ & -0.001955 & $-8.58 \mathrm{E}-06$ & $5.40 \mathrm{E}-05$ & 0.022406 \\
\hline 6 & $4.89 \mathrm{E}-05$ & $6.77 \mathrm{E}-05$ & $5.50 \mathrm{E}-05$ & -0.001971 & $-8.65 \mathrm{E}-06$ & $5.44 \mathrm{E}-05$ & 0.022405 \\
\hline 7 & $4.91 \mathrm{E}-05$ & $6.79 \mathrm{E}-05$ & $5.51 \mathrm{E}-05$ & -0.001976 & $-8.67 \mathrm{E}-06$ & $5.46 \mathrm{E}-05$ & 0.022405 \\
\hline 8 & $4.91 \mathrm{E}-05$ & $6.79 \mathrm{E}-05$ & $5.52 \mathrm{E}-05$ & -0.001977 & $-8.68 \mathrm{E}-06$ & $5.46 \mathrm{E}-05$ & 0.022405 \\
\hline 9 & $4.91 \mathrm{E}-05$ & $6.79 \mathrm{E}-05$ & $5.52 \mathrm{E}-05$ & -0.001978 & $-8.68 \mathrm{E}-06$ & $5.47 \mathrm{E}-05$ & 0.022405 \\
\hline 10 & $4.91 \mathrm{E}-05$ & $6.79 \mathrm{E}-05$ & $5.52 \mathrm{E}-05$ & -0.001978 & $-8.68 \mathrm{E}-06$ & $5.47 \mathrm{E}-05$ & 0.022405 \\
\hline \multicolumn{8}{|c|}{ Nonfactorized One Std. Dev. Shock } \\
\hline
\end{tabular}


The Innovation accounting completes itself with the Forecast Error Variance Decomposition Analysis. Unlike the Granger causality test, it provides some more information on the strength of a causal relationship between economic variables in addition to the direction of such a causal relationship [76]. In the cases where the causal relationship may be statistically insignificant, we can use forecast error variance decomposition analysis to measure the relative importance of other economic variables in influencing a particular economic variable [67]. Thus the analysis is carried on by this study for a future period of 10 months for "one standard deviation" innovation in stock prices and macroeconomic variables. We have used all the significant cointegrating ranks and followed the order of the variables similar to the Impulse Response Analysis. The results are shown in Table 11.

Table 11. Variance decomposition analysis.

\begin{tabular}{|c|c|c|c|c|c|c|c|c|}
\hline \multicolumn{9}{|c|}{ Variance Decomposition of LNINDEX: } \\
\hline Period & S.E. & LNINDEX & YTB & YLGB & LNIIP & LNWPI & LNM3 & LNEX \\
\hline 1 & 0.085652 & 100.0000 & 0.000000 & 0.000000 & 0.000000 & 0.000000 & 0.000000 & 0.000000 \\
\hline 2 & 0.121502 & 99.77465 & $2.46 \mathrm{E}-05$ & 0.001196 & 0.222748 & $7.35 \mathrm{E}-05$ & 0.000260 & 0.001052 \\
\hline 3 & 0.149109 & 99.58590 & $4.52 \mathrm{E}-05$ & 0.002198 & 0.409317 & 0.000135 & 0.000477 & 0.001933 \\
\hline 4 & 0.172397 & 99.45874 & $5.91 \mathrm{E}-05$ & 0.002873 & 0.535006 & 0.000176 & 0.000623 & 0.002527 \\
\hline 5 & 0.192907 & 99.37353 & $6.84 \mathrm{E}-05$ & 0.003325 & 0.619224 & 0.000204 & 0.000721 & 0.002924 \\
\hline 6 & 0.211441 & 99.31432 & $7.49 \mathrm{E}-05$ & 0.003639 & 0.677751 & 0.000224 & 0.000790 & 0.003201 \\
\hline 7 & 0.228478 & 99.27138 & $7.96 \mathrm{E}-05$ & 0.003867 & 0.720192 & 0.000238 & 0.000839 & 0.003401 \\
\hline 8 & 0.244331 & 99.23902 & $8.31 \mathrm{E}-05$ & 0.004039 & 0.752183 & 0.000248 & 0.000876 & 0.003552 \\
\hline 9 & 0.259215 & 99.21381 & $8.59 \mathrm{E}-05$ & 0.004173 & 0.777098 & 0.000256 & 0.000905 & 0.003670 \\
\hline 10 & 0.273291 & 99.19365 & $8.81 \mathrm{E}-05$ & 0.004280 & 0.797031 & 0.000263 & 0.000929 & 0.003764 \\
\hline \multicolumn{9}{|c|}{ Variance Decomposition of YTB: } \\
\hline Period & S.E. & LNINDEX & YTB & YLGB & LNIIP & LNWPI & LNM3 & LNEX \\
\hline 1 & 0.573015 & 0.021291 & 99.97871 & 0.000000 & 0.000000 & 0.000000 & 0.000000 & 0.000000 \\
\hline 2 & 0.812481 & 0.013811 & 99.34062 & 0.003427 & 0.638174 & 0.000210 & 0.000744 & 0.003014 \\
\hline 3 & 0.997450 & 0.010308 & 98.80427 & 0.006292 & 1.171844 & 0.000386 & 0.001365 & 0.005534 \\
\hline 4 & 1.153638 & 0.008368 & 98.44331 & 0.008218 & 1.530592 & 0.000505 & 0.001783 & 0.007229 \\
\hline 5 & 1.291229 & 0.007161 & 98.20172 & 0.009507 & 1.770599 & 0.000584 & 0.002063 & 0.008362 \\
\hline 6 & 1.415557 & 0.006347 & 98.03399 & 0.010402 & 1.937215 & 0.000639 & 0.002257 & 0.009149 \\
\hline 7 & 1.529829 & 0.005763 & 97.91244 & 0.011050 & 2.057952 & 0.000679 & 0.002398 & 0.009719 \\
\hline 8 & 1.636144 & 0.005325 & 97.82086 & 0.011538 & 2.148916 & 0.000709 & 0.002504 & 0.010149 \\
\hline 9 & 1.735961 & 0.004985 & 97.74956 & 0.011919 & 2.219732 & 0.000732 & 0.002586 & 0.010483 \\
\hline 10 & 1.830344 & 0.004713 & 97.69254 & 0.012223 & 2.276369 & 0.000751 & 0.002652 & 0.010751 \\
\hline \multicolumn{9}{|c|}{ Variance Decomposition of YLGB: } \\
\hline Period & S.E. & LNINDEX & YTB & YLGB & LNIIP & LNWPI & LNM3 & LNEX \\
\hline 1 & 0.343770 & 0.002542 & 5.970977 & 94.02648 & 0.000000 & 0.000000 & 0.000000 & 0.000000 \\
\hline 2 & 0.485608 & 0.005194 & 6.001649 & 93.77473 & 0.217073 & $7.16 \mathrm{E}-05$ & 0.000253 & 0.001025 \\
\hline 3 & 0.594559 & 0.006874 & 6.014802 & 93.57508 & 0.400750 & 0.000132 & 0.000467 & 0.001893 \\
\hline 4 & 0.686460 & 0.007927 & 6.021786 & 93.44175 & 0.525267 & 0.000173 & 0.000612 & 0.002481 \\
\hline 5 & 0.767444 & 0.008617 & 6.026056 & 93.35250 & 0.609038 & 0.000201 & 0.000710 & 0.002876 \\
\hline 6 & 0.840666 & 0.009092 & 6.028922 & 93.29042 & 0.667417 & 0.000220 & 0.000778 & 0.003152 \\
\hline 7 & 0.908004 & 0.009437 & 6.030974 & 93.24534 & 0.709836 & 0.000234 & 0.000827 & 0.003352 \\
\hline 8 & 0.970681 & 0.009696 & 6.032515 & 93.21132 & 0.741859 & 0.000245 & 0.000864 & 0.003504 \\
\hline 9 & 1.029550 & 0.009899 & 6.033714 & 93.18479 & 0.766828 & 0.000253 & 0.000893 & 0.003622 \\
\hline 10 & 1.085230 & 0.010061 & 6.034674 & 93.16355 & 0.786822 & 0.000259 & 0.000917 & 0.003716 \\
\hline
\end{tabular}




\section{Continued}

\begin{tabular}{|c|c|c|c|c|c|c|c|c|}
\hline \multicolumn{9}{|c|}{ Variance Decomposition of LNIIP: } \\
\hline Period & S.E. & LNINDEX & YTB & YLGB & LNIIP & LNWPI & LNM3 & LNEX \\
\hline 1 & 0.053782 & 0.701415 & 0.248088 & 0.217468 & 98.83303 & 0.000000 & 0.000000 & 0.000000 \\
\hline 2 & 0.056924 & 0.813228 & 0.385752 & 0.194325 & 98.36710 & 0.012709 & 0.044898 & 0.181990 \\
\hline 3 & 0.057489 & 0.894219 & 0.522653 & 0.216941 & 97.71608 & 0.034484 & 0.121823 & 0.493802 \\
\hline 4 & 0.057763 & 0.959423 & 0.655548 & 0.259164 & 97.00075 & 0.059679 & 0.210834 & 0.854602 \\
\hline 5 & 0.057999 & 1.018076 & 0.785273 & 0.307929 & 96.27143 & 0.085786 & 0.303062 & 1.228443 \\
\hline 6 & 0.058228 & 1.073910 & 0.912556 & 0.358367 & 95.54519 & 0.111920 & 0.395387 & 1.602676 \\
\hline 7 & 0.058454 & 1.128248 & 1.037729 & 0.408831 & 94.82743 & 0.137793 & 0.486791 & 1.973177 \\
\hline 8 & 0.058679 & 1.181546 & 1.160940 & 0.458787 & 94.11977 & 0.163317 & 0.576963 & 2.338680 \\
\hline 9 & 0.058903 & 1.233967 & 1.282264 & 0.508071 & 93.42255 & 0.188469 & 0.665819 & 2.698855 \\
\hline 10 & 0.059126 & 1.285577 & 1.401756 & 0.556640 & 92.73575 & 0.213247 & 0.753356 & 3.053677 \\
\hline \multicolumn{9}{|c|}{ Variance Decomposition of LNWPI: } \\
\hline Period & S.E. & LNINDEX & YTB & YLGB & LNIIP & LNWPI & LNM3 & LNEX \\
\hline 1 & 0.006114 & 0.591327 & 0.918313 & 0.134016 & 7.812745 & 90.54360 & 0.000000 & 0.000000 \\
\hline 2 & 0.008635 & 0.588424 & 0.919765 & 0.131680 & 7.555010 & 90.80509 & $5.99 \mathrm{E}-06$ & $2.43 \mathrm{E}-05$ \\
\hline 3 & 0.010568 & 0.586808 & 0.920557 & 0.130389 & 7.413282 & 90.94891 & $1.11 \mathrm{E}-05$ & $4.49 \mathrm{E}-05$ \\
\hline 4 & 0.012198 & 0.585838 & 0.921029 & 0.129616 & 7.328627 & 91.03482 & $1.45 \mathrm{E}-05$ & $5.89 \mathrm{E}-05$ \\
\hline 5 & 0.013634 & 0.585213 & 0.921332 & 0.129119 & 7.274175 & 91.09008 & $1.69 \mathrm{E}-05$ & $6.83 \mathrm{E}-05$ \\
\hline 6 & 0.014932 & 0.584784 & 0.921539 & 0.128778 & 7.236855 & 91.12795 & $1.85 \mathrm{E}-05$ & $7.49 \mathrm{E}-05$ \\
\hline 7 & 0.016126 & 0.584474 & 0.921689 & 0.128531 & 7.209901 & 91.15530 & $1.97 \mathrm{E}-05$ & $7.97 \mathrm{E}-05$ \\
\hline 8 & 0.017238 & 0.584241 & 0.921802 & 0.128346 & 7.189596 & 91.17591 & $2.05 \mathrm{E}-05$ & $8.33 \mathrm{E}-05$ \\
\hline 9 & 0.018282 & 0.584059 & 0.921890 & 0.128201 & 7.173773 & 91.19197 & $2.12 \mathrm{E}-05$ & $8.61 \mathrm{E}-05$ \\
\hline 10 & 0.019270 & 0.583914 & 0.921960 & 0.128085 & 7.161105 & 91.20483 & $2.18 \mathrm{E}-05$ & $8.83 \mathrm{E}-05$ \\
\hline \multicolumn{9}{|c|}{ Variance Decomposition of LNM3: } \\
\hline Period & S.E. & LNINDEX & YTB & YLGB & LNIIP & LNWPI & LNM3 & LNEX \\
\hline 1 & 0.010146 & 0.263361 & 0.079418 & 0.638389 & 0.339714 & 0.074236 & 98.60488 & 0.000000 \\
\hline 2 & 0.014654 & 0.186020 & 0.068680 & 0.476308 & 5.552069 & 0.059245 & 93.64030 & 0.017372 \\
\hline 3 & 0.018247 & 0.147863 & 0.062564 & 0.393737 & 9.205898 & 0.051274 & 90.10766 & 0.031006 \\
\hline 4 & 0.021300 & 0.126687 & 0.058977 & 0.347306 & 11.48711 & 0.046717 & 87.89345 & 0.039759 \\
\hline 5 & 0.023985 & 0.113667 & 0.056724 & 0.318603 & 12.95380 & 0.043880 & 86.46788 & 0.045440 \\
\hline 6 & 0.026404 & 0.104993 & 0.055210 & 0.299439 & 13.94802 & 0.041981 & 85.50105 & 0.049305 \\
\hline 7 & 0.028621 & 0.098846 & 0.054133 & 0.285847 & 14.65734 & 0.040633 & 84.81114 & 0.052066 \\
\hline 8 & 0.030678 & 0.094277 & 0.053332 & 0.275740 & 15.18593 & 0.039630 & 84.29697 & 0.054124 \\
\hline 9 & 0.032607 & 0.090752 & 0.052713 & 0.267943 & 15.59411 & 0.038857 & 83.89991 & 0.055714 \\
\hline 10 & 0.034427 & 0.087952 & 0.052222 & 0.261748 & 15.91851 & 0.038242 & 83.58435 & 0.056978 \\
\hline \multicolumn{9}{|c|}{ Variance Decomposition of LNEX: } \\
\hline Period & S.E. & LNINDEX & YTB & YLGB & LNIIP & LNWPI & LNM3 & LNEX \\
\hline 1 & 0.022544 & 0.062718 & 0.043599 & 0.146569 & 0.608063 & 3.504168 & 0.876622 & 94.75826 \\
\hline 2 & 0.031772 & 0.072279 & 0.042625 & 0.165086 & 0.324947 & 3.508500 & 0.864040 & 95.02252 \\
\hline 3 & 0.038847 & 0.077753 & 0.042064 & 0.175619 & 0.217355 & 3.509130 & 0.856625 & 95.12145 \\
\hline 4 & 0.044815 & 0.081074 & 0.041724 & 0.181994 & 0.164349 & 3.509095 & 0.852079 & 95.16969 \\
\hline 5 & 0.050075 & 0.083224 & 0.041503 & 0.186118 & 0.133087 & 3.508969 & 0.849123 & 95.19798 \\
\hline 6 & 0.054832 & 0.084702 & 0.041351 & 0.188951 & 0.112412 & 3.508855 & 0.847088 & 95.21664 \\
\hline 7 & 0.059209 & 0.085772 & 0.041241 & 0.191001 & 0.097685 & 3.508764 & 0.845616 & 95.22992 \\
\hline 8 & 0.063283 & 0.086578 & 0.041158 & 0.192545 & 0.086647 & 3.508694 & 0.844505 & 95.23987 \\
\hline 9 & 0.067110 & 0.087206 & 0.041094 & 0.193750 & 0.078060 & 3.508638 & 0.843639 & 95.24761 \\
\hline 10 & 0.070731 & 0.087709 & 0.041042 & 0.194715 & 0.071189 & 3.508594 & 0.842946 & 95.25381 \\
\hline \multicolumn{9}{|c|}{ Cholesky Ordering: LNINDEX YTB YLGB LNIIP LNWPI LNM3 LNEX } \\
\hline
\end{tabular}


The findings of the variance decomposition analysis reinforce the results of the impulse response analysis and causality tests with a greater degree of clarity. At the sample horizons, forecast error variance in stock prices is explained mainly by itself (100 to 99.2 percent) and the individual explaining ability of the other macroeconomic variables is negligible (less than one percent and IIP come out as the best performer amongst the others, see Table 11). Gunasekarage et al. [32], also reported similar observations in the context of Sri Lanka. Again, the forecast error variance of industrial production is weakly explained by the stock prices (which are little over one percent on and from the fifth month) although the rates are increasing gradually over the future forecasted period of the study. The results of the variance decomposition analysis grossly support the findings of the prima-facie Granger-causal relation, that is, the stock market activity has a positive impact to lead the Indian real sector. The forecast error variances of other macroeconomic variables are best explained by the respective variables themselves and very marginally explained by the stock prices. The secondary focus of the findings of innovation accounting indicates the supplementary role of output in the context of the Indian asset market.

In essence, the overall results of the innovation accounting confirm the findings of Granger causality tests. The observations also reveal that the market itself is the most active determinant to influence its own behavior.

\section{Conclusions}

The link and influence of macroeconomic variables on aggregate stock prices and vice versa is an issue of intense debate for the last few years. Relying on the current but widely used robust econometric tools, the present paper attempts to investigate the dynamic relation between the stock prices and select macroeconomic variables, at levels, covering the post liberalization period of Indian economy.

Problem with this type of analysis is, for a number of variables it is unclear how and exactly in which manner a particular parameter influences market activities. This may be due to the presence of innumerable events that interfere in the relationship and influence asset prices. However, findings of cointegrating relationship between explanatory variables and stock market behavior more or less satisfy our general intuitive feeling and economic theory. But, at the same time, observation of this study brings the conclusions of the efficient market hypothesis in doubt. All the findings from co-integration analysis, Granger casualty and innovation analysis suggest a pattern of relationship that very precisely may be stated as-Indian stock market leads the economic activities and the core determinants of the asset market are the market itself, IIP, money supply and exchange market. This is of course encouraging but self sensitivity of the market and weak influence of other macroeconomic variables on its functioning is a disturbing phenomenon which indicates that there is an urgent need to improve the market efficiency.

\section{References}

[1] Fama, E. (1981) Stock Returns, Real Activity, Inflation and Money. American Economic Review, 71, 545-565.

[2] Fama, E.F. and French, K.R. (1988) Dividend Yield and Expected Stock Returns. Journal of Financial Economics, 25, 23-49.

[3] Bilson, C.M., Brailsford, T.J. and Hooper, V.J. (2001) Selecting Macroeconomic Variables as Explanatory Factors of Emerging Stock Market Returns. Pacific-Basin Finance Journal, 9, 401-426.

[4] Wongbangpo, P. and Sharma, S.C. (2002) Stock Market and Macroeconomic Fundamental Dynamic Interactions: ASEAN-5 Countries. Journal of Asian Economics, 13, 27-51. http://dx.doi.org/10.1016/S1049-0078(01)00111-7

[5] AL-Sharkas, A. (2004) The Dynamic Relationship between Macroeconomic Factors and the Jordanian Stock Market. International Journal of Applied Econometrics and Quantitative Studies, 1, 97-114.

[6] Menzly, L., Santos, T. and Veronesi, P. (2004) Understanding Predictability. Journal of Political Economy, 112, 16-41.

[7] Chancharoenchai, K., Lu, S.D. and Mathur, I. (2005) Stock Returns and the Macroeconomic Environment Prior to the Asian Crisis in Selected Southeast Asian Countries. Emerging Markets Finance and Trade, 41, 38-56.

[8] Rapach, D.E., Wohar, M.E. and Rangvid, J. (2005) Macro Variables and International Stock Return Predictability. International Journal of Forecasting, 21, 137-166. http://dx.doi.org/10.1016/j.ijforecast.2004.05.004

[9] Paye, B.S. and Timmermann, A. (2006) Instability of Return Prediction Models. Journal of Empirical Finance, 13, 274-315. http://dx.doi.org/10.1016/j.jempfin.2005.11.001

[10] Piazzesi, M., Schneider, M. and Tuzel, S. (2007) Housing, Consumption, and Asset Pricing. Journal of Financial Economics, 83, 531-569. http://dx.doi.org/10.1016/j.jfineco.2006.01.006 
[11] Rangvid, J. (2006) Output and Expected Returns. Journal of Financial Economics, 81, 595-624. http://dx.doi.org/10.1016/j.jfineco.2005.07.010

[12] Ray, H. (2007) Macroeconomic Variables and Stock Market Behaviour: An Indian Experience. Artha Vijñāna, 49, 255-274.

[13] Sharma, J.L. (1983) Efficient Capital Markets and Random Character of Stock Price Behavior in a Developing Economy. Indian Economic Journal, 31, 53-57.

[14] Pethe, A. and Karnik, A. (2000) Do Indian Stock Markets matter? Stock Market Indices and Macro-Economic Variables. Economic and Political Weekly, 35, 349-356.

[15] Bulmash, S.B. and Trivoli, G.W. (1991) Time-Lagged Interactions between Stock Prices and Selected Economic Variables. The Journal of Portfolio Management, 17, 66-67. http://dx.doi.org/10.3905/jpm.1991.409351

[16] Darrat, A.F. and Mukherjee, T.K. (1987) The Behavior of the Stock Market in a Developing Economy. Economics Letters, 22, 273-278.

[17] Pal, K. and Mittal, R. (2011) Impact of Macroeconomic Indicators on Indian Capital Markets. The Journal of Risk Finance, 12, 84-97.

[18] Naka, A., Mukherjee, T.K. and Tufte, D. (2001) Microeconomic Variables and the Performance of the Indian Stock Market. Working Paper 1998-06, University of New Orleans, New Orleans.

[19] Deb, S.S. (2003) In Search of Weak Form of Efficiency in Indian Capital Market. The ICFAI Journal of Applied Finance, 9, 31-50.

[20] Cochrane, J. (1999) New Facts in Finance. Economic Perspectives, Federal Reserve Bank of Chicago, 23, 39-58.

[21] Döpke, J., Hartmann, D. and Pierdzioch, C. (2006) Forecasting Stock Market Volatility with Macroeconomic Variables in Real Time. Discussion Paper Series 2: Banking and Financial Studies No 01/2006.

[22] Demirguc-Kunt, A. and Levine, R. (1996) Stock Markets, Corporate Finance, and Economic Growth: An Overview. World Bank Economic Review, 10, 223-239. http://dx.doi.org/10.1093/wber/10.2.223

[23] Fry, M.J. (1978) Money Capital or Financial Deepening in Economic Development. Journal of Money, Credit and Banking, 10, 464-475. http://dx.doi.org/10.2307/1991576

[24] Arestis, P., Demetriades, P.O. and Luintel, K.B. (2001) Financial Development and Economic Growth: The Role of Stock Markets. Journal of Money, Credit and Banking, 33, 16-41. http://dx.doi.org/10.2307/2673870

[25] Agarwal, P. (2004) Interest Rate and Investment in East Asia: An Empirical Evaluation of Various Financial Liberalisation Hypothesis. Journal of Development Studies, 40, 142-173. http://dx.doi.org/10.1080/0022038042000213238

[26] Schwert, G.W. (1989) Why Does Stock Market Volatility Change over Time? Journal of Finance, 44, 1115-1153. http://dx.doi.org/10.1111/j.1540-6261.1989.tb02647.x

[27] Asprem, M. (1989) Stock Prices, Asset Portfolios and Macroeconomic Variables in Ten European Countries. Journal of Banking and Finance, 13, 589-612. http://dx.doi.org/10.1016/0378-4266(89)90032-0

[28] Kwon, C.S., Shin, T.S. and Bacon, F.W. (1997) The Effect of Macroeconomic Variables on Stock Market Returns in Developing Markets. Multinational Business Review, 5, 63.

[29] Wong, W.K., Agarwal, A. and Du, J. (2004) Financial Integration for Indian Stock Market: A Fractional Co-Integration Approach. Finance India, 18, 1581-604.

[30] Guo, H. (2003) On the Real-Time Forecasting Ability of the Consumption-Wealth Ratio. Discussion Paper 2003-007B, Federal Reserve Bank of St. Louis.

[31] Clark, T.E. and Kozicki, S. (2004) Estimating Equilibrium Real Interest Rates in Real-Time. Bundesbank Discussion Paper 32/2004, Deutsche Bundesbank, Frankfurt.

[32] Gunasekarage, A., Pisedtasalasai, A. and Power, D.M. (2004) Macroeconomic Influence on the Stock Market: Evidence from an Emerging Market in South Asia. Journal of Emerging Market Finance, 3, 285-304.

[33] Sollis, R. (2005) Predicting Returns and Volatility with Macroeconomic Variables: Evidence from Test of Encompassing. Journal of Forecasting, 24, 221-231. http://dx.doi.org/10.1002/for.956

[34] Chen, N.F., Roll, R. and Ross, S.A. (1986) Economic Forces and the Stock Market. Journal of Business, 59, $383-403$. http://dx.doi.org/10.1086/296344

[35] McMillan, D.G. (2001) Cointegration Relationships between Stock Market Indices and Economic Activity: Evidence from US Data. Discussion Paper from the Department of Economics, University of St. Andrews, St. Andrews.

[36] Reily, F. K. and Brown, K.C. (2002) Investment Analysis and Portfolio Management. The Dryden Press, Orlando.

[37] Abdullah, D.A. and Hayworth, S.C. (1993) Macroeconomics of Stock Price Fluctuations. Quarterly Journal of Busi- 
ness and Economics, 32, 50-67.

[38] Nasseh, A. and Strauss, J. (2000) Stock Prices and Domestic and International Macroeconomic Activity: A Cointegration Approach. Quarterly Review of Economics and Finance, 40, 229-245. http://dx.doi.org/10.1016/S1062-9769(99)00054-X

[39] Obstfeld, M. (1994) Risk-Taking, Global Diversification, and Growth. American Economic Review, 84, $1310-1329$.

[40] Hsing, Y. (2004) Impacts of Fiscal Policy, Monetary Policy, and Exchange Rate Policy on Real GDP in Brazil: A VAR Model. Brazilian Electronic Journal of Economics, 6, 1-12.

[41] DeFina, R.H. (1991) Does Inflation Depress the Stock Market? Business Review, Federal Reserve Bank of Philadelphia, Nov-Dec, 3-12.

[42] Shen, P. (1998) How Important Is the Inflation Risk Premium? Economic Review, Federal Reserve Bank of Kansas City (fourth quarter), 35-47.

[43] MacKinnon, R.I. (1973) Money and Capital in Economic Development. The Brookings Institute, Washington DC.

[44] Shaw, E.S. (1973) Financial Deepening in Economic Development. Oxford University Press, New York.

[45] Mukharjee, T.K. and Naka, A. (1995) Dynamic Relation between Macroeconomic Variables and the Japanese Stock Market: An Application of Vector Error Correction Model. Journal of Financial Research, 18, 223-237.

[46] Ma, C.K. and Kao, G.W. (1990) On Exchange Rate and Stock Price Reaction. Journal of Business Finance and Accounting, 17, 441-449. http://dx.doi.org/10.1111/j.1468-5957.1990.tb01196.x

[47] Soenen, L.A. and Hennigar, E.S. (1988) An Analysis of Exchange Rates, and Stock Prices-The U.S. Experience between 1980 and 1986. Akron Business and Economic Review, 19, 7-16.

[48] Dimitrova, D. (2005) The Relationship between Exchange Rates and Stock Prices: Studied in a Multivariate Model. Issues in Political Economy, 14. http://www.elon.edu/e-web/students/ipe/default.xhtml

[49] Libanio, G.A. (2005) Unit Roots in Macroeconomic Time Series: Theory, Implications and Evidence. Nova Economia Belo Horizonte, 15, 145-176. http://dx.doi.org/10.1590/S0103-63512005000300006

[50] Atiq-ur-Rehman and AsadZaman (2008) Model Specification, Observational Equivalence and Performance of Unit Root Tests. Munich Personal RePEc Archive Paper, No. 13489. http://mpra.ub.uni-muenchen.de/13489

[51] Said, S. and Dicky, D.A. (1984) Testing for Unit Roots in Autoregressive-Moving Average Models of Unknown Order. Biometrika, 71, 599-607. http://dx.doi.org/10.1093/biomet/71.3.599

[52] Elliott, G., Rothenberg, T. J. and Stock, J.H. (1996) Efficient Test for an Autoregressive Unit Root. Econometrica, 64, 813-836. http://dx.doi.org/10.2307/2171846

[53] Ng, S. and Perron, P. (2001) Lag Length Selection and the Construction of Unit Root Tests with Good Size and Power. Econometrica, 69, 1519-1554. http://dx.doi.org/10.1111/1468-0262.00256

[54] Schwarz, G. (1978) Estimating the Dimension of a Model. Annals of Statistics, 6, 461-464. http://dx.doi.org/10.1214/aos/1176344136

[55] Akaike, H. (1974) A New Look at the Statistical Model Identification. IEEE Transactions on Automatic Control, 19, 716-723. http://dx.doi.org/10.1109/TAC.1974.1100705

[56] Hannan, E.J. and Quinn, B.G. (1979) The Determination of the Order of an Autoregression. Journal of the Royal Statistical Society, Series-B, 41, 190-195.

[57] Schollhammer, H. and Sand, O. (1985) The Interdependence among the Stock Markets of Major European Countries and United States: An Empirical Investigation of Interrelationships among National Stock price Movements. International Management Review, 25, 17-25.

[58] Eun, C. and Shim, S. (1989) International Transmission of Stock Market Movements. Journal of Financial and Quantitative Analysis, 24, 241-256.

[59] Hassan, M.K. and Naka, A. (1996) Short-Run and Long-Run Dynamic Linkages among International Stock Markets. International Review of Economics and Finance, 5, 387-405. http://dx.doi.org/10.1016/S1059-0560(96)90025-8

[60] Johansen,S. (1991) Estimation and Hypothesis Testing of Cointegration Vectors in Gaussian Vector Autoregression models. Econometrica, 59, 1551-1580. http://dx.doi.org/10.2307/2938278

[61] Johansen,S. (1995) Likelihood Based Inference in Cointegrated Vector Autoregressive Models. Oxford University Press, Oxford. http://dx.doi.org/10.1093/0198774508.001.0001

[62] Johansen, S. and Juselius, K. (1990) Maximum Likelihood Estimation and Procedure for Inference on Cointegration with Application to the Demand for Money. Oxford Bulletin of Economics and Statistics, 52, 169-210. http://dx.doi.org/10.1111/j.1468-0084.1990.mp52002003.x

[63] Johansen, S. and Juselius, K. (1994) Identification of the Long-Run and the Short-Run Structure. An Application of the 
ISLM Model. Journal of Econometrics, 63, 7-36. http://dx.doi.org/10.1016/0304-4076(93)01559-5

[64] Engle, R.F. and Granger, C.W.J. (1987) Co-Integration and Error Correction: Representation, Estimation and Testing. Econometrica, 55, 251-276. http://dx.doi.org/10.2307/1913236

[65] Kasa, K. (1992) Common Stochastic Trends in International Stock Markets. Journal of Monetary Economics, 29, 95124. http://dx.doi.org/10.1016/0304-3932(92)90025-W

[66] Serlatis, A. and King, M. (1997) Common Stochastic Trends and Convergence of European Union Stock Markets. The Manchester School of Economics \& Social Studies, 65, 44-57. http://dx.doi.org/10.1111/1467-9957.00042

[67] Yang, J., Balyeat, R.B. and Leatham, D.J. (2005) Futures Trading Activity and Commodity Cash Price Volatility. Journal of Business Finance \& Accounting, 32, 297-323. http://dx.doi.org/10.1111/j.0306-686X.2005.00595.X

[68] Adjasi, C., Harvey, S.K. and Agyapong, D. (2008) Eeffects of Exchange Rate Volatility on the Ghana Stock Exchange. African. Journal of Accounting, Economics, Finance and Banking Research, 3, 28-47.

[69] Maysami, R.C. and Koh, T.S. (2000) A Vector Error Correction Model of the Singapore Stock Market. International Review of Economics and Finance, 9, 79-96. http://dx.doi.org/10.1016/S1059-0560(99)00042-8

[70] Ray, H. (2008) Dynamic Interactions of Exchange Rates, Stock Prices and Macroeconomic Variables in India. The ICFAI Journal of APPLIED FINANCE, 14, 19-33.

[71] Rajput, A. and Thaker, K. (2008) Exchange Rate, FII and Stock Index Relationship in India. Vilakshan, XIMB Journal of Management, 43-56.

[72] Puah, C.H. and Jayraman, T.K. (2007) Macroeconomic Activities and Stock Prices in a South Pacific Island Economy. International Journal of Economics and Management, 1, 229-244.

[73] Jhunjhunwala, B. (2008) The Dollar Crisis. The Statesman, 04-01-2008.

[74] Greene, W.H. (2006) Econometric Analysis. Pearson, New Delhi.

[75] Lütkepohl, H. and Reimers, H.E. (1992) Impulse Response Analysis of Cointegrated Systems. Journal of Economic Dynamics and Control, 16, 53-78. http://dx.doi.org/10.1016/0165-1889(92)90005-Y

[76] Sims, C. (1980) Macroeconomics and Reality. Econometrica, 48, 1-48. http://dx.doi.org/10.2307/1912017 